DOI: 10.34015/2523-4552.2019.4.12

УдК 342.9

Шиян О. А. аспірант Інституту держави і права ім. В.М. Корецького НАН України ORCID: 0000-0002-9419-1324

\title{
ДО ПИТАННЯ СУБ'ЄКТІВ ФОРМУВАННЯ ТА РЕАЛІЗАЦІЇ ДЕРЖАВНОЇ ІННОВАЦІЙНОЇ ПОЛІТИКИ
}

У статті досліджується система органів державної влади, уповноважених на формування та реалізацію інноваційної політики в Україні. Розглядається питання розмежування функцій з формування та реалізації інноваційної політики. Пропонується внесення змін до чинного законодавства для покращення правового регулювання інноваційної діяльності в Україні.

Ключові слова. державне регулювання; інноваційна діяльність; формування та реалізація інноваційної політики; інновації.

В статье исследуется система органов государственной власти, уполномоченных на формирование и реализацию инновационной политики в Украине. Рассматривается вопрос о разграничении функций по формированию и реализации инновационной политики. Предлагается внесение изменений в действующее законодательство для улучшения правового регулирования инновационной деятельности в Украине.

Ключевые слова. государственное регулирование; инновационная деятельность; формирование и реализация инновационной политики; инновации.

Постановка проблеми. Інноваційна діяльність $є$ найважливішим чинником якісного вдосконалення та розвитку різних сфер життя суспільства. Перехід до інтелектуально орієнтованої моделі розвитку $\epsilon$ для України єдино можливим шляхом до реального досягнення європейських стандартів життя своїх громадян, рівноправного входження в коло розвинутих країн Європи і світу.

Особливий інтерес представляють питання організаційної структури державного управління суспільними відносинами у сфері інноваційної діяльності, адже без наявності такої структури не можливо здійснити належний владно-організую- чий вплив на національну інноваційну систему України.

Аналіз останніх досліджень i публікацій. Варто зазначити, що питанням правового регулювання державного управління присвячено досить багато праць, в тому числі таких відомих науковців як В. Б. Аверянов, О.Ф. Андрійко, Ю. П. Битяк,

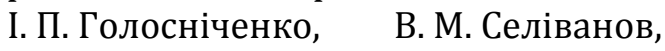
В. П. Нагребельний тощо. При цьому проблемам правового регулювання саме інноваційної діяльності присвячено праці таких науковців як Ю. Є. Атаманова, Т. В. Васильченка, О. В. Голяшкіна, С. І. Федчук тощо. Разом з тим, питанню організаційноправового регулювання інноваційної 
діяльності приділено досить мало уваги.

Постановка завдання. Дослідити систему органів державної влади, уповноважених на формування та реалізацію державної інноваційної політики. Запропонувати оптимізацію структури органів державної влади у сфері інноваційної діяльності.

Виклад основного матеріалу. Організаційною структурою державних органів у сфері інноваційної діяльності можна розглядати сукупність взаємопов'язаних органів державної влади, що знаходяться між собою у стійких організаційноправових відносинах, та забезпечують функціонування і розвиток інноваційної сфери.

3 нашої точки зору, суб'єктів організаційно-правового регулювання суспільних відносин у сфері інноваційної діяльності в Україні доцільно поділити на суб'єктів загальної та спеціальної компетенції.

До повноважень суб'єктів загальної компетенції належать питання правового регулювання суспільних відносин в різних сферах державного управління, в тому числі і у сфері організаційно-правового регулювання інноваційної діяльності. До таких суб'єктів можна віднести: 1) Верховну Раду України; 2) Президента України; 3) Кабінет Міністрів України; 4) міністерства та інші центральні органи виконавчої влади; 5) Раду Міністрів АРК; 6) місцеві державні адміністрації; 7) Верховну Раду АРК; 8) органи місцевого самоврядування.

В межах даної статті особливу увагу приділимо суб'єктам спеціальної компетенції, які здійснюють організаційно-правове регулювання інноваційної діяльності як одну із своїх основних функцій. На сьогоднішній день такими суб'єктами $€$ Міністерство освіти і науки України (МОН України) та Міністерство розвитку економіки, торгівлі та сільського господарства (Мінекономіки). Зазначені суб'єкти мають особливий статус, адже саме на них покладено основне завдання формування та реалізації державної інноваційної політики.

Варто зазначити, що 0. С. Попович стосовно суб'єкта спеціальної компетенції зазначає, що міжгалузева специфіка науковотехнологічної та інноваційної політики, їі спрямованість на соціальноекономічний розвиток країни в цілому зумовлює необхідність надання йому таких повноважень, які забезпечували б можливості впливу не тільки на наукові дослідження і розробку новітніх технологій, але й забезпечували їх використання у всіх без винятку галузях економіки. Саме таким «надміністерським» органом державної влади мислив С. М. Рябченко (перший Голова Комітету - авт.), створюючи в 1991 році Комітет по науково-технічному прогресу при Кабінеті міністрів України [1, c. 34]. Відповідно до положення про вказаний Комітет, яке було затверджено постановою КМУ від 12 лютого 1992 р. N 72 [2] рішення Комітету з питань, що належать до його компетенції, $\epsilon$ обов'язковими для виконання всіма міністерствами, відомствами та організаціями України.

Сам орган спеціальної компетенції у сфері інноваційної діяльності починаючи з 1991 року неодноразово зазнавав реорганізації. Зазначене можна прослідкувати зі зміни йо- 
го назви, що відповідно відображало зміну і його компетенції:

1991 р. - Комітет з питань науково-технічного прогресу;

1992 р. - Державний комітет 3 питань науки і техніки;

1995 р. - Державний комітет 3 питань науки, техніки і промислової політики;

1996 р. - Міністерство у справах науки і технологій;

1998 р. - Державний комітет 3 питань науково-технічного та інноваційного розвитку;

2000 р. - Підрозділи Міністерства освіти і науки України;

2005 р. - Державне агентство України з інвестицій та інновацій;

2010 р. (з квітня по липень) Державний комітет України з питань науково-технічного та інноваційного розвитку;

2010 р. (з 5 липня по 9 грудня) - Державний комітет України 3 питань науки, інновацій та інформатизації;

2011 р. - Державне агентство 3 питань науки, інновацій та інформатизації України;

2013 р. - Державне агентство 3 питань науки і технологій;

2014 р. і до цього часу - два підрозділи Міністерства освіти і науки України [див. там же, ст. 35].

2014 р. і до нині - підрозділ Міністерства розвитку економіки, торгівлі та сільського господарства.

Станом на сьогодні Міністерство освіти і науки України діє відповідно до Положення про Міністерство освіти і науки України, яке затверджене постановою Кабінету Міністрів України від 16 жовтня 2014 р. № 630 [3]. Так, згідно $з$ п. 1 Положення про МОН Міністерство освіти і науки України є центральним орга- ном виконавчої влади, діяльність якого спрямовується і координується Кабінетом Міністрів України. МОН $\epsilon$ головним органом у системі центральних органів виконавчої влади, що забезпечує формування та реалізує державну політику у сферах освіти i науки, наукової, науковотехнічної та інноваційної діяльності в науковій сфері, трансферу (передачі) технологій, а також забезпечує формування та реалізацію державної політики у сфері здійснення державного нагляду (контролю) за діяльністю закладів освіти, підприємств, установ та організацій, які надають послуги у сфері освіти або провадять іншу діяльність, пов'язану з наданням таких послуг, незалежно від їх підпорядкування і форми власності.

МOH у своїй діяльності керується Конституцією та законами України, указами Президента України і постановами Верховної Ради України, прийнятими відповідно до Конституції та законів України, актами Кабінету Міністрів України, іншими актами законодавства (п. 2 Положення про МОН). Відповідно до п.п. 1 п. 3 Положення одним із основних завдань МОН $\epsilon$ забезпечення формування та реалізація державної політики у сферах освіти і науки, наукової, науково-технічної діяльності та інноваційної діяльності в науковій сфері, трансферу (передачі) технологiü.

Відповідно до Положення про Мінекономіки, яке затверджене постановою Кабінету Міністрів України від 20 серпня 2014 р. № 459 (в редакції постанови Кабінету Міністрів України від 11 вересня 2019 р. № 838) [4], Мінекономіки є головним органом у системі центральних органів виконавчої влади, що забезпе- 
чує формування та реалізує державну політику економічного, соціального розвитку і торгівлі, державну промислову політику, державну військово-промислову політику, державну інвестиційну політику, державну зовнішньоекономічну політику, державну політику у сфері технічного регулювання, стандартизації, метрології та метрологічної діяльності, управління об'єктами державної власності, розвитку підприємництва, державно-приватного партнерства, інтелектуальної власності, інноваційної діяльності в реальному сектоpi економіки, туризму та курортів (крім здійснення державного нагляду (контролю) у сфері туризму та курортів), державних та публічних закупівель, а також державного замовлення на підготовку фахівців, наукових, науково-педагогічних та робітничих кадрів, підвищення кваліфікації та перепідготовку кадрів.

Відповідно до п.п 1 п. 3 Положення про Міністерство розвитку економіки, торгівлі та сільського господарства одним із основних завдань Мінекономіки є забезпечення формування та реалізація державної інноваційної політики в реальному секторі економіки.

Відтак, ми бачимо, що станом на сьогодні існує так званий дуалізм у організаційно-правовому регулюванні інноваційної діяльності суб'єктами спеціальної компетенції, зокрема:

- МОН України формує та реалізує інноваційну політику у сфері науки та трансферу (передачі) технологій;

- Мінекономіки України формує та реалізує інноваційну політику у сфері реального сектора економіки.
Звертається увага, що вказаний вище дуалізм двох міністерств у сфеpi формування та реалізації інноваційної політики був зумовлений підписанням між Першим віце-прем'єрміністром-Міністром економічного розвитку і торгівлі Степаном Кубівим та Міністром освіти і науки Лілією Гриневич протоколу щодо розподілу повноважень у сфері інновацій. Так, за повідомленням Мінекономіки на офіційному веб-сайті органів виконавчої влади «Урядовий портал» від 18 травня 2018 року: МОН зосередиться на тому, щоб створити умови для підготовки винахідників та формуватиме інноваційне середовище в школах, вишах, наукових установах тощо. Міністерство також працюватиме над створенням комунікаційних платформ для спілкування винахідників та бізнесу, розвитком менторських програм. Водночас Мінекономрозвитку створюватиме умови для комерціалізації винаходів та ініціатив у реальному секторі економіки [5].

Звертається увага, що структура ст. 9 «Повноваження центральних органів виконавчої влади у сфері інноваційної діяльності» Закону України «Про інноваційну діяльність» містить дві частини:

- у першій частині висвітлено повноваження Центрального органу виконавчої влади, що забезпечує формування державної політики у сфері інновацій;

- у другій частині висвітлено повноваження Центрального органу виконавчої влади, що реалізує державну політику у сфері науковотехнічної та інноваційної діяльності.

Вбачається, що дві згаданих вище частини стосується як Міністерства освіти і науки України так і 
Міністерства розвитку економіки, торгівлі та сільського господарства як центральних органів виконавчої влади, які забезпечують формування та реалізують державну інноваційну політику.

У цьому контексті звертаємо увагу, що у згаданій ст. 9 Закону України «Про інноваційну діяльність» відсутній будь-який поділ функцій центрального органу виконавчої влади на:

- формування та реалізацію інноваційної політики у сферах науки;

- формування та реалізацію інноваційної політики у сфері реального сектору економіки.

Відтак, можна допустити, що наразі відбувається певне дублювання функцій МOH та Мінекономіки у сфері державного регулювання інноваційної діяльності. Так, наприклад, у ч. 2 ст. 9 Закону України «Про інноваційну діяльність» зазначено, що центральний орган виконавчої влади, що реалізує державну політику у сфері науково-технічної та інноваційної діяльності готує пропозиції щодо визначення пріоритетних напрямів розвитку інноваційної діяльності. Таким центральним органом $є$ МОН у частині формування та реалізації державної політики у сфері інноваційної діяльності в науці, трансферу (передачі) технологій та Мінекономіки у частині формування та реалізації державної інноваційної політики у сфері реального сектора економіки. Відтак, постає запитання: який із вказаних органів відповідно до ч. 2 ст. 9 Закону України «Про інноваційну діяльність» має підготувати пропозиції щодо визначення пріоритетних напрямів розвитку інноваційної діяльності?
Зазначимо, що в цілому нами підтримуються ініціативи щодо активізації Мінекономіки у сфері інноваційної діяльності, адже сутність інноваційних процесів найбільш тяжіє саме до суспільно-економічних відносин. Більше того, з нашої точки зору, доцільно було б передбачити повноваження щодо формування та реалізації інноваційної політики у інших сферах і іншим органам виконавчої влади. Наприклад, функції 3 формування та реалізації інноваційної політики у сфері соціального захисту населення можна було б надати Міністерству соціальної політики; функції з формування та реалізації інноваційної політики у сфері ядерної енергетики, паливно-енергетичного комплексу, відновлювальних джерел енергії - Міністерству енергетики та захисту довкілля тощо.

Такий підхід найбільш повно відображає позицію щодо всепроникненості (дифузії) явища інновації у різні сфери життя суспільства. Більше того, такий підхід $є$ в певній мір не новий, адже організаційноправове регулювання інноваційної діяльності у різних сферах життя суспільства за часів СРСР здійснювали відповідні структурні підрозділи міністерств та відомств. Основні їх функції визначались Типовим положенням про підрозділ патентноліцензійної, винахідницької і раціоналізаторської роботи міністерства (відомства), затвердженим постановою Державного комітету у справах винаходів і відкриттів при ДКНТ СРСР від 25 липня 1985 року (за погодженням із різними центральними органами влади СРСР).

Разом $з$ тим, закріплення за різними міністерствами функцій щодо формування та реалізації інновацій- 
ної політики в тій чи іншій сфері потребує законодавчого забезпечення та внесення відповідних змін до ст. 9 Закону України «Про інноваційну діяльність».

Варто також звернути увагу, що станом на сьогодні як МОН України, так і Мінекономіки займаються формуванням та реалізацією інноваційної політики. Так, у структурі МОН України наявні такі підрозділи, які займаються інноваційною сферою:

- Директорат інновацій та трансферу технологій, який згідно 3 Положенням про Директорат є самостійним структурним підрозділом апарату Міністерства освіти і науки України (МОН), утвореним для виконання завдань, пов'язаних із забезпеченням формування державної політики у сфері інновацій та трансферу технологій [6];

- Головне управління із забезпечення реалізації державної політики у сферах інноваційної діяльності та трансферу технологій [7], яке займається реалізацією державної політики у зазначених сферах.

У структурі Мінекономіки наявний лише один структурний підрозділ - Департамент інвестицій та інновацій [8].

Як ми бачимо у структурі МОН формуванням та реалізацією інноваційної політики займаються різні структурні підрозділи. Зауважимо, що МОН України не завжди акумулювало в собі функції з формування та реалізації інноваційної політики. Так, відповідно до Положення про Державне агентство з питань науки, інновацій та інформатизації України, затверджене указом Президента України від 8 квітня 2011 року N 437/2011 [9], саме на Держінформ- науки покладались функції з реалізація державної політики у сфері наукової, науково-технічної, інноваційної діяльності, трансферу технологій, інформатизації, формування, використання і захисту державних електронних інформаційних ресурсів та створення умов для розвитку інформаційного суспільства. Станом на сьогодні Держінформнауки ліквідовано, а функції з реалізації державної інноваційної політики передано до МОН України та Мінекономіки.

Зауважимо, що у Концепції оптимізації системи центральних органів виконавчої влади, схваленої розпорядженням Кабінету Міністрів України від 27 грудня 2017 р. № 1013-p [10] у розділі «Упорядкування системи центральних органів виконавчої влади» передбачено, що основними завданнями міністерств $€$ стратегічне планування діяльності, забезпечення формування державної політики, координація та проведення моніторингу її реалізації. Діяльність міністерств повинна бути зосереджена насамперед на розробленні документів у відповідних сферах державної політики та проектів актів законодавства, інші центральні органи виконавчої влади можуть надавати міністерствам пропозиції щодо коригування державної політики та удосконалення законодавства у відповідних сферах. Обсяг функцій з реалізації державної політики в міністерствах повинен бути мінімальним. При цьому, у цьому ж розділі Концепції зазначено, що окремі функції 3 реалізації державної політики можуть виконуватися міністерствами, зокрема за таких умов:

функції з реалізації державної політики мають стратегічне значення для держави; 
- функції з реалізації державної політики нерозривно пов'язані із забезпеченням формування державної політики у відповідній сфері;

- обсяг і зміст функцій з реалізації державної політики не обумовлює доцільності утворення нового центрального органу виконавчої влади або передачі їх існуючим органам виконавчої влади, органам місцевого самоврядування чи іншим суб'єктам.

3 нашої точки зору, функції з реалізації інноваційної політики мають стратегічне значення для України, такі функції нерозривно пов'язані із забезпеченням формування державної політики у відповідній сфері. Обсяг та зміст функцій з реалізації державної політики не спонукає до утворення нового органу державної влади, особливо при умові формування інноваційної політики на рівні різних міністерств. Така ситуація може призвести до надмірного нагромадження різних ЦОВВ з реалізації державної інноваційної політики в різних сферах.
3 нашої точки зору, акумулювання в МОН України функцій формування та реалізації інноваційної політики є доцільним. При цьому, заслуговує на увагу підхід щодо розділення цих функцій у МОН між різними структурними підрозділами, що 3 нашої точки зору $є$ більш виправдано, ніж акумуляція функцій формування та реалізації інноваційної політики в одному структурному підрозділі Мінекономіки.

Висновки. Підсумовуючи зазначимо, що в процесі виконання своїх функцій суб'єкти загальної компетенції та суб'єкти спеціальної компетенції знаходяться в тісному взаємозв'язку. Підтримується позиція щодо надання функцій з формування та реалізації інноваційної політики різним міністерствам. При цьому, функції з формування та функції з реалізації інноваційної політики варто розділити на рівні різних структурних підрозділів відповідних міністерств.

\section{Список використаних джерел}

1. Попов О. С. Науково-технологічна та інноваційна політика: основні механізми формування та реалізації: Київ : Інститут досліджень науково-технічного потенціалу та історії науки ім. Г. М. Доброва НАН України, 2019. 342 с.

2. Про затвердження Положення про Комітет по науково-технічному прогресу при Кабінеті Міністрів України: постанова КMУ. URL: https://zakon.rada.gov.ua/laws/show/72-92-\%D0\%BF (дата звернення: 21.12.2019).

3. Положення про Міністерство освіти і науки України, затверджене постановою Кабінету Міністрів України від 16 жовтня 2014 р. № 630. Офіційний вісник України. 2014. № 95. С. 17.

4. Положення про Міністерство розвитку економіки, торгівлі та сільського господарства України, затверджене постановою Кабінету Міністрів України від 20 серпня 2014 р. № 459 (в редакції постанови Кабінету Міністрів України від 11 вересня 2019 р. № 838). Офіційний вісник України. 2014. № 77. С. 116.

5. МОН та Мінекономрозвитку домовилися про розподіл повноважень у сфері інновацій. URL: https://www.kmu.gov.ua/news/mon-ta-minekonomrozvitku-domovilisyapro-rozpodil-povnovazhen-u-sferi-innovacij (дата звернення: 21.12.2019). 
6. Положення про директорат інновацій та трансферу технологій. URL: https://mon.gov.ua/ua/ministerstvo/pro-ministerstvo/direktorati/direktorat-innovacij-tatransferu-tehnologij (дата звернення: 21.12.2019).

7. Головне управління із забезпечення реалізації державної політики у сфеpax інноваційної діяльності та трансферу технологій. URL: https://mon.gov.ua/ua/ministerstvo/pro-ministerstvo/kontaktna-informaciya/strukturnipidrozdili-mon/direktorat-innovacij-ta-transferu-tehnologij (дата звернення: 21.12.2019).

8. Органіграма Міністерства розвитку економіки, торгівлі та сільського господарства. URL: http://www.me.gov.ua/Documents/Detail?lang=uk-UA\&id=983e66e6dfd0-400e-b1b5-d0c6d64a6377\&title=StrukturaMinisterstva2019 (дата звернення: 21.12.2019).

9. Положення про Державне агентство з питань науки, інновацій та інформатизації України, затверджене указом Президента України від 8 квітня 2011 року N 437/2011. Офіційний вісник України. 2011 р. № 29. С. 188.

10. Концепція оптимізації системи центральних органів виконавчої влади, схвалена розпорядженням Кабінету Міністрів України від 27 грудня 2017 р. № 1013-р. Офіційний вісник України. 2018 р. № 9. С. 64.

\section{References}

1. Popov, O.S. (2019). Naukovo-tekhnolohichna ta innovatsiina polityka: osnovni mekhanizmy formuvannia ta realizatsii. Kyiv: Instytut doslidzhen naukovo-tekhnichnoho potentsialu ta istorii nauky im. H. M. Dobrova NAN Ukrainy [in Ukrainian].

o. Shyian, Postgraduate Student of the V.M. Koretsky Institute of state and law of National Academy of Sciences of Ukraine ORCID: 0000-0002-9419-1324

\section{Concerning the subjects of formation and implementation of state innovation policy}

In the article it has been outlined the subjects of general and special competence in the sphere of innovative activity. It has been noted that the competences of authorities of general competence include the issues of legal regulation of public relations in various spheres of public administration, including in the sphere of organizational and legal regulation of innovation activity. These authorities includes: 1) the Verkhovna Rada of Ukraine; 2) the President of Ukraine; 3) the Cabinet of Ministers of Ukraine; 4) ministries and other central executive bodies; 5) the Council of Ministers of the ARC; 6) local state administrations; 7) The Verkhovna Rada of the ARC; 8) local self-government bodies.

The subjects of special competence are the bodies that regulate the innovation activity as one of its main functions. As of today such authorities includes the Ministry of Education and Science of Ukraine (MES of Ukraine) and the Ministry of Development of Economy, Trade and Agriculture (Ministry of Economy). These bodies have a special status, because they have the main task in regulation of state innovation policy. 
In the process of performing its functions, the authorities of general competence and authorities of special competence were closely interrelated. In the article has been supported a view of providing functions for the formation and implementation of innovational policy by the different ministries. This position maintained because of the exceptional strategic importance of innovation for the development and normal functioning of the country. At the same time, the functions of formation and functions of implementation of innovational policy should be divided between the different structural units of the relevant ministries.

It has been also drawn an attention to the certain shortcomings in Art. 9 of the Law of Ukraine "On Innovative Activities" on the allocation of functions of the special competence state body.

Keywords: state regulation; innovative activity; formation and implementation of innovation polic; innovation. 